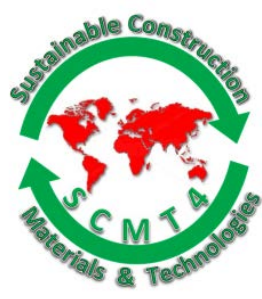

SCMT4

Las Vegas, USA, August 7-11, 2016

\title{
How SCMs Improve Concrete Durability - A Fundamental View
}

\author{
Harald Justnes
}

SINTEF Building and Infrastructure, Pb. 4760 Sluppen, 7465 Trondheim, Norway. E-mail: <harald.justnes@sintef.no>.

\begin{abstract}
The influence of supplementary cementing materials (SCMs) on the hydration and durability of blended cement has been evaluated using chemical and physical principles. Similarities and differences between various SCMs has been considered while they have been grouped into categories as latent hydraulic or pozzolanic and sub-divided into siliceous, aluminous, carbonaceous etc. For instance has the important synergy between SCMs producing calcium aluminate hydrate and calcium carbonate been elucidated showing how maximizing water binding leads to reduced porosity and thereby increased strength by forming calcium monocarboaluminate hydrate. Similarly would any magnesium content in the carbonate lead to hydrotalcite formation in the presence of aluminates.
\end{abstract}

The interaction of admixtures with SCMs, like plasticizers, and the use of accelerators to speed up hydration are also treated.

The influence of SCMs on durability issues like chloride ingress, carbonation, alkali aggregate reactions, sulphate resistance and freeze-thaw resistance is discussed as well. The importance of not accelerating the durability exposure too much is stressed in order avoid creation of products from the SCMs that will not occur in practice. Generally speaking SCMs improve the resistance of blended cements to most degradation mechanisms at equal w/c, with the exception of carbonation that can be improved by reducing w/c.

\section{INTRODUCTION}

\section{Reasons for extended use of SCMs}

The cement industry world-wide is calculated to bring about $5-8 \%$ of the total global anthropogenic carbon dioxide $\left(\mathrm{CO}_{2}\right)$ emissions. The general estimate is about 1 tonne of $\mathrm{CO}_{2}$ emission per tonne clinker produced, if fossil fuel is used and no measures are taken to reduce it. The $3^{\text {rd }}$ rank after heating/cooling of buildings and transport is not because cement is such a bad material with respect to $\mathrm{CO}_{2}$ emissions, but owing to the fact that it is so widely used to construct the infrastructure and buildings of modern society as we know it. Concrete is actually among the more environmentally friendly materials since it is composed in general of about 1 part cement, 0.5 parts water and 5-6 parts of sand and gravel (i.e. aggregate). The world's cement production was roughly 4 billion tonnes in 2013, meaning roughly 24 billion tonnes concrete or 10 billion $\mathrm{m}^{3}$ concrete. This quantity can be translated into making a concrete 
cylinder of about $20 \mathrm{~cm}$ diameter reaching the moon and back to earth every day or building a solid concrete block with $1 \mathrm{~km}^{2}$ base reaching higher $(10000 \mathrm{~m})$ than Mount Everest $(8848 \mathrm{~m})$ in a year!

A lot is done by cement producers to reduce the global carbon footprint, in particular to replace coal with waste having a calorific value equivalent to (fossil) fuel and by making blended cement where parts of the clinker is replaced with supplementary cementing materials (SCMs). However, cement is a bulk product that should cover a wide range of applications and serve different customers, giving limitations on clinker replacements.

Concrete, on the other hand, is the end product where the performance criteria are already specified and depending on application more can be done to increase its sustainability. As pointed out by Justnes [2013] the shortest route to make cement and concrete more sustainable, is to replace clinker in cement or cement in concrete by supplementary cementing materials (SCMs). This paper discusses how SCMs affect cement and concrete principally in chemical and physical ways and what this means in terms of durability.

\section{Classes of SCMs}

One can divide SCMs into latent hydraulic and pozzolanic. Latent hydraulic SCMs are inorganic additives that only need an activator to react with water and form a cementitious binder. Examples are ground, granulated blast furnace slag (GGBS), synthetic calcium aluminate glasses and to some extent high calcium fly ash. Pozzolanic SCMs are mineral additives that form cementitious binders in reaction with calcium hydroxides. Pozzolanic SCMs can be sub-divided by their major oxides like silicas (e.g. silica fume, nano-silica, rice husk ash, hydrothermal silica and diatomaceous earth or kieselgur), aluminosilicates (e.g. siliceous fly ash, calcined clays like metakaolin, burnt shale and natural pozzolana of volcanic origin like trass, scoria etc) and alumina (e.g. nano-alumina). Lothenbach et al. [2011] have given an overview of the performance of the most common SCMs (i.e. silica fume, fly ash and GGBS) in blended cements, while Thomas [2013] published a book on SCMs in concrete. Carbonates as SCM are in a class by itself since they need aluminate hydrates to react with and they were for a long time considered inert, or at best accelerating the cement setting acting as nucleation sites, since there were relatively little aluminate in cement clinker not tied up by sulphates to ettringite and thereby the carbonate reactivity was difficult to observe. However, the reactivity of calcium carbonate becomes first observable on a macro level in ternary systems with fly ash producing extra calcium aluminate hydrates in its pozzolanic reaction [De Weerdt and Justnes, 2009] and recently the strength increase of fly ash blended cement with dolomite versus limestone was found to be due to hydrotalcite formation also requiring aluminates [Zajac et al., 2014].

\section{Physical principles}

The physical principles include particle packing, pore refinement and connectivity of pores reducing the transport of aggressives into the concrete. The two latter points are actually indirectly chemical since they are a consequence of hydration and depend on how much liquid water is transferred into solid hydrates. The effect improves as a function of time.

\section{Chemical principles}

The chemical principles involve the chemical nature of the hydration products and how they interact with aggressives forming new products. 


\section{PHYSICAL EFFECTS OF SCM}

\section{Initial particle packing}

SCMs have often higher surface and consist of smaller particles than portland cement and also lower density. Hence, in the practical approach of just replacing cement with SCM by mass, there will be an increased volume of binder (cement + SCM + water) relative to the aggregate. The same goes for adding SCM to cement instead of replacing cement, which is common in many former studies, in particular for silica fume. In more scientific studies it is therefore recommended to use volume replacement of cement by SCM in order to sort out the physical and chemical effects of the SCM compared to cement.

If one considers a portland cement with average particle size $d_{50} \approx 20 \mu \mathrm{m}$, it still has a particle size distribution (psd) allowing smaller particles to pack in between the larger particles. For a particle with radius $r$ to fit into a tetrahedral hole created by 4 spheres of $20 \mu$ m diameter (radius $R=10 \mu \mathrm{m}) ; r<(\sqrt{ } 3 / 2$ $-1) \mathrm{R}=2.25 \mu \mathrm{m}$, and to fit in an octahedral hole of 6 spheres of diameter $20 \mu \mathrm{m} ; \mathrm{r}<(\sqrt{2}-1) \mathrm{R}=4.14 \mu \mathrm{m}$. An individual silica fume particle of $0.15 \mu \mathrm{m}$ can then even fit into a tetrahedral hole of cement particles as small as $1.33 \mu \mathrm{m}$ in diameter, while calcined clay particles with a typical diameter of $5 \mu \mathrm{m}$ only can pack in between coarser cement particles and compete with cement grains of similar size.

The simplest SCM example is silica fume [Justnes, 2007] consisting of basically spherical individual particles with an average diameter of $0.15 \mu \mathrm{m}$, although usually occurring as aggregation of fused particles. As comparison, the irregular grains of a portland cement have typical average diameter of 15-20 $\mu \mathrm{m}$. The chemical composition of silica fume (SF) is also rather simple as it usually contains more than $90 \% \mathrm{SiO}_{2}$ with a range of 85 to $99 \%$. Because of its small particle size, SF will pack in the cavities formed by the irregular shaped cement grains until a certain dosage when the SF will disperse cement grains or its agglomerates in the fresh state. The result is a considerable void size refinement from the start.

Reduced permeability during setting, or shortly thereafter, is important for durability of concrete (for instance in marine environment) when made by slip forming or when demoulded early. Ingress of aggressive ions like water-borne chlorides can be very rapid during early exposure, in particular due to suction created by the under pressure in contraction pores formed as a consequence of hydration.Increased volume of solids

\section{Increased volume of solids}

Hydration reactions lead normally to an increased volume of solids as liquid water is transformed into hydrates. The strength increase after initial contact between the particles is mainly a consequence of reduced porosity, even though the mechanical properties of the formed compounds matters as well. One can use alite hydration as an illustrative example:

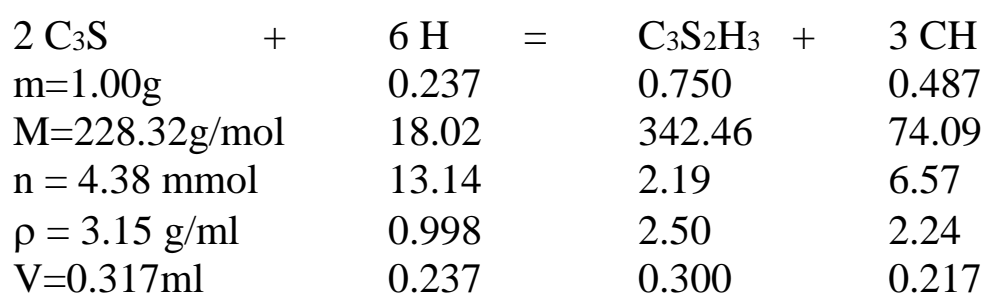

where the increase in volume of solids during hydration is $(0.300+0.217)-0.317=0.200 \mathrm{ml}$ per 
gram $\mathrm{C}_{3} \mathrm{~S}$ corresponding to an increase of 63 vol\%.

\section{CHEMICAL EFFECTS OF SCM}

Scrivener et al. [2015] published a state of the art on methods to determine the degree of reaction of SCMs. The chemical effects of different SCMs are treated in the following:

\section{Silica}

Using the cement chemist's notation the pozzolanic reaction of silica fume can be written:

$\mathrm{S}+\mathrm{CH}=\mathrm{CSH}$

A mixture of silica fume and pure lime needs weeks to harden properly. The acceleration of the pozzolanic reaction by alkalis creating high $\mathrm{pH}$ in the pore water was confirmed by Justnes [1995] following the strength development for mortars with lime/silica fume cementitious materials. The presence of alkalis seems to serve as a catalyst for a rapid pozzolanic reaction of silica fume $(\mathrm{aq}=$ aqueous, $\mathrm{s}=$ solid $)$ :

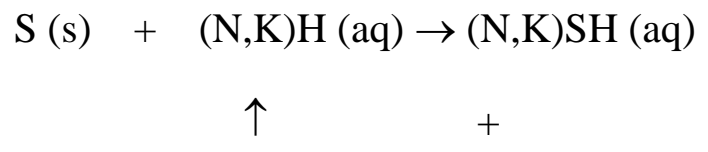

$$
\mathrm{CSH}(\mathrm{s})+(\mathrm{N}, \mathrm{K}) \mathrm{H}(\mathrm{aq}) \leftarrow \mathrm{CH}(\text { aq or } \mathrm{s})
$$

The nature of the CSH-gel from the pozzolanic reaction is different than the CSH gel formed by cement hydration. The two different gels coming from the cement hydration and the pozzolanic reaction, respectively, can be interwoven. The calcium silicate hydrate amorphous gel can exist in a wide range of compositions. The general difference between CSH from pozzolanic reaction and from cement hydration is that the former CSH has longer linear polysilicate anions and lower C/S-ratio than the latter [Justnes 1992].

In Fig. 1 [Justnes 1998] the relative compressive strength of mortar with lime/SF cementitious material (corresponding to $\mathrm{C} / \mathrm{S}=1.11$, water-to-solid $=0.70$ and alkalis of $\mathrm{K} / \mathrm{Na}=2$ to $\mathrm{pH}=13$ ) is plotted versus curing time. In the same figure the degree of reaction of $\mathrm{SF}$ as measured by ${ }^{29} \mathrm{Si}$ MAS NMR versus curing time is plotted as well with a nearly identical trend indicating linearity between SF conversion and strength.

Justnes et al. [1990, 1992] used ${ }^{29}$ Si MAS NMR to study the influence of silica fume on the hydration rate of the silicate phases (sum of alite and belite) in ordinary and high strength cement, as well as the rate of silica fume reaction in such blends and the overall composition of the CSH gel under sealed conditions. Justnes et al. [1992] and Sellevold et al. [1992] showed that for low $\mathrm{w} /(\mathrm{c}+\mathrm{s})$, the silica fume reacted faster than cement and left cement grains as microaggregate embedded in the CSH-gel. However, this is not necessarily negative for strength as cement grains are quite hard particles. Furthermore, some unreacted cement has potential in contributing to self-healing of microcracks during the service life of concrete. 


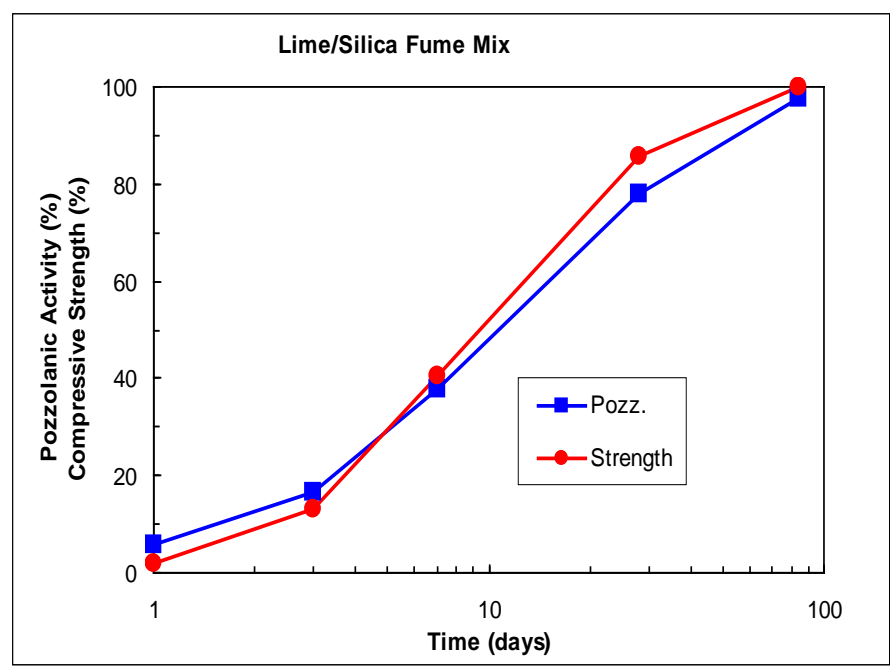

Figure 1 Comparison of compressive strength (relative to $63.9 \mathrm{MPa}$ at 84 days $=100 \%$ ) development of mortar with reactivity of silica fume in the cementitious material lime /SF with $\mathrm{C} / \mathrm{S}=1.11$ and water-to-solid ratio 0.70 after Justnes [1998].

\section{Alumina and aluminosilicates}

The chemical reaction of alumina, as in for instance nano-alumina [e.g. Barbhuiya et al., 2014] or simply $\gamma-\mathrm{Al}_{2} \mathrm{O}_{3}$, is equally simple as for silica in reaction (2);

$3 \mathrm{CH}+\mathrm{A}+3 \mathrm{H}=\mathrm{C}_{3} \mathrm{AH}_{6}$

$\mathrm{C}_{3} \mathrm{AH}_{6}$ is the stable end-product in an isolated system of finely divided alumina and lime in spite of a number of metastable calcium aluminate hydrates $\left(\mathrm{CAH}_{10}, \mathrm{C}_{4} \mathrm{AH}_{19}\right.$ etc). As for silica in reaction (3), alkalis will also here play a catalytic role with soluble aluminum hydroxide ions like $\mathrm{Al}(\mathrm{OH}) 4^{-}$as the likely intermediate product. The difference is that the $\mathrm{CAH}$ products in general are crystalline rather than amorphous.

The pozzolanic reaction of the aluminosilicate (AS) glass phase in fly ash and the distorted aluminosilicate layers in calcined clays is complex but can be written in a non-balanced way;

$$
\mathrm{CH}+\mathrm{AS}+\mathrm{H} \rightarrow \mathrm{CSH}+\mathrm{CAH}+\mathrm{CASH}
$$

A representative for calcium aluminate hydrate $(\mathrm{CAH})$ will be $\mathrm{C}_{3} \mathrm{AH} 6$ and the mixed product CASH can be Strätlingite; $\mathrm{C}_{2} \mathrm{ASH}$. In addition to that, it is typical that the $\mathrm{CSH}$-gel will contain more aluminate than when it is formed by cement hydration only.

Ground blast-furnace slag (GGBS) contains sufficient calcium to react by itself when activated by alkalis. GGBS has a typical composition of $47 \% \mathrm{CaO}+\mathrm{MgO}, 35 \% \mathrm{SiO}_{2}$ and $12 \% \mathrm{Al}_{2} \mathrm{O}_{3}$. When activated with gypsum together with cement, the hydration products of slag are generally the same as for ordinary Portland cement (OPC); CSH-gel, Ettringite and monosulphate 
[Smocsyk, 1965, and Uchikawa, 1986]. The formation of Strätlingite $\left(\mathrm{C}_{2} \mathrm{ASH} \mathrm{H}_{8}\right.$ is only to be expected if alkali hydroxide is added to the slag cement according to Richartz [1966] or if the blast furnace slag is activated with alkali hydroxide [Regourd, 1980, and Forss, 1983]. Like fly ash, GGBS has a somewhat variable composition and it may not be entirely true that it does not consume calcium hydroxide during its reaction [Hinrichs and Odler, 1989], which may depend on its content of $\mathrm{CaO}$ relative to $\mathrm{SiO}_{2}$ and $\mathrm{Al}_{2} \mathrm{O}_{3}$. The introduction of more calcium aluminate hydrate in the system by GGBS will destabilize ettringite (AFt) and form more calcium monosulphate hydrate (AFm), as for fly ash (Fig. 2).

\section{Carbonates}

Carbonates need CAH to react with. The combination of limestone together with an aluminate containing pozzolan (e.g. fly ash) makes calcium carbonate react more since it is too little CAH available from the clinker. This synergistic reaction lead to more bound water, reduced porosity and thereby higher strength has been documented by De Weerdt and Justnes [2008 and 2009], as well as De Weerdt et al. [2010 and 2011a,b,c,d].

The synergetic effect between fly ash and limestone powder is attributed to the impact of $\mathrm{CaCO}_{3}$ on the AFm phases which has been documented for pure OPC [Lothenbach et al., 2008]. AFm can in general be written $\left[\mathrm{Ca}_{2}(\mathrm{Al}, \mathrm{Fe})(\mathrm{OH})_{6}\right] \mathrm{X} \cdot \mathrm{xH}_{2} \mathrm{O}$ where $\mathrm{X}$ denotes one formula unit of a singly charged anion or half a formula unit of a doubly charged anion (e.g. $\mathrm{OH}^{-}, \mathrm{SO}_{4}{ }^{2-}$ or $\mathrm{CO}_{3}{ }^{2-}$ often referred to as $\mathrm{OH}-\mathrm{AFm}, \mathrm{SO}_{4}-\mathrm{AFm}$ and $\mathrm{CO}_{3}-\mathrm{AFm}$. The impact of limestone powder is amplified as fly ash provides additional aluminates to the system by its pozzolanic reaction with calcium hydroxide from the cement hydration. The effect is demonstrated by Eqs. 6 and 7 showing the increased volume of the hydration phases in the reactions. The remains and original boundary of a partial reacted limestone grain in a cement-fly ash-limestone blend is shown in Fig. 2.

It is beneficial to blend calcium carbonate with something forming either more $\mathrm{C}_{3} \mathrm{AH}_{6}$ or sulphate-AFm that can react with calcium carbonate to bind more water and increase volume;

\begin{tabular}{|c|c|c|c|}
\hline C므 & $\mathrm{C}_{3} \mathrm{AH}_{6}+$ & $5 \mathrm{H}$ & $\mathrm{C}_{4} \mathrm{~A}_{\underline{C H}} \mathrm{H}_{11}$ \\
\hline $\mathrm{m}=1.00 \mathrm{~g}$ & 3.78 & 0.90 & 5.68 \\
\hline $\mathrm{M}=100.09 \mathrm{~g} / \mathrm{mol}$ & 378.29 & 18.02 & 568.50 \\
\hline $\mathrm{n}=9.99 \mathrm{mmol}$ & 9.99 & 49.95 & 9.99 \\
\hline$\rho=2.67 \mathrm{~g} / \mathrm{ml}$ & 2.52 & 0.998 & 2.17 \\
\hline $\mathrm{V}=0.375 \mathrm{ml}$ & 1.500 & 0.902 & 2.618 \\
\hline
\end{tabular}

According to the reaction in Eq. 6, $100 \mathrm{~g}$ calcium carbonate $(\approx 1 \mathrm{~mol})$ would bind $90 \mathrm{~g}(\approx 5 \mathrm{~mol})$ extra water. The total increase in volume of solids is then $(2.618-(0.375+$ $1.500)) \cdot 100 \mathrm{vol} \% /(0.375+1.500)=39.6 \mathrm{vol} \%$. So with a lot of $\mathrm{C}_{3} \mathrm{AH}_{6}$ produced, this will matter. Alternatively, the reaction with sulphate AFm will be as in Eq. 7. According to the reaction in Eq. $7,100 \mathrm{~g}$ calcium carbonate $(\approx 1 \mathrm{~mol})$ would bind $162 \mathrm{~g}(\approx 9 \mathrm{~mol})$ extra water. The total increase in volume of solids is then $((3.526+2.618)-(0.375+4.630)) \cdot 100 \mathrm{vol} \% /(0.375+4.630)=$ $22.8 \mathrm{vol} \%$. This is just above half the volume increase compared to limestone reacting directly with $\mathrm{C}_{3} \mathrm{AH}_{6}$ in Eq. 6. 


\begin{tabular}{lrrrr}
\multicolumn{1}{c}{$2 \mathrm{CC}$} & $3 \mathrm{C}_{4} \mathrm{AS}_{\underline{S}} H_{12}+18 \mathrm{H}=2 \mathrm{C}_{4} \mathrm{ACH}_{11}+\mathrm{C}_{6} \mathrm{~A}_{\underline{S}} \underline{H}_{32}$ \\
$\mathrm{~m}=1.00 \mathrm{~g}$ & 9.33 & 1.62 & 5.68 & 6.27 \\
$\mathrm{M}=100.09 \mathrm{~g} / \mathrm{mol}$ & 622.52 & 18.02 & 568.50 & 1255.11 \\
$\mathrm{n}=9.99 \mathrm{mmol}$ & 14.99 & 89.91 & 9.99 & 5.00 \\
$\rho=2.67 \mathrm{~g} / \mathrm{ml}$ & 2.015 & 0.998 & 2.17 & 1.778 \\
$\mathrm{~V}=0.375 \mathrm{ml}$ & 4.630 & 1.623 & 2.618 & 3.526
\end{tabular}

Small additions of limestone powder result in the formation of calcium hemicarboaluminate hydrate ("hemicarbonate") instead of calcium monosulphoaluminate hydrate ("monosulphate") and thereby stabilizing ettringite. Larger limestone additions leads to the formation of calcium monocarboaluminate hydrate ("monocarbonate"). Due to the difference in specific volume of these phases, and higher amount of hydrate water in ettringite or AFt (32 mole) vs. AFm (12 mole), an increase in the total volume of hydration phases can be observed. This will in turn lead to a reduction in porosity and consequently to an increase in strength. Segments of XRD profiles of paste showing how phases shift for different mixes of cement, cement with fly ash (FA), cement with limestone (L) and cement with limestone and fly ash (FA/L) are plotted in Fig. 2. The validity of the synergistic effect of limestone/fly ash for different clinker types and fly ash types was documented by De Weerdt et al. [2013].

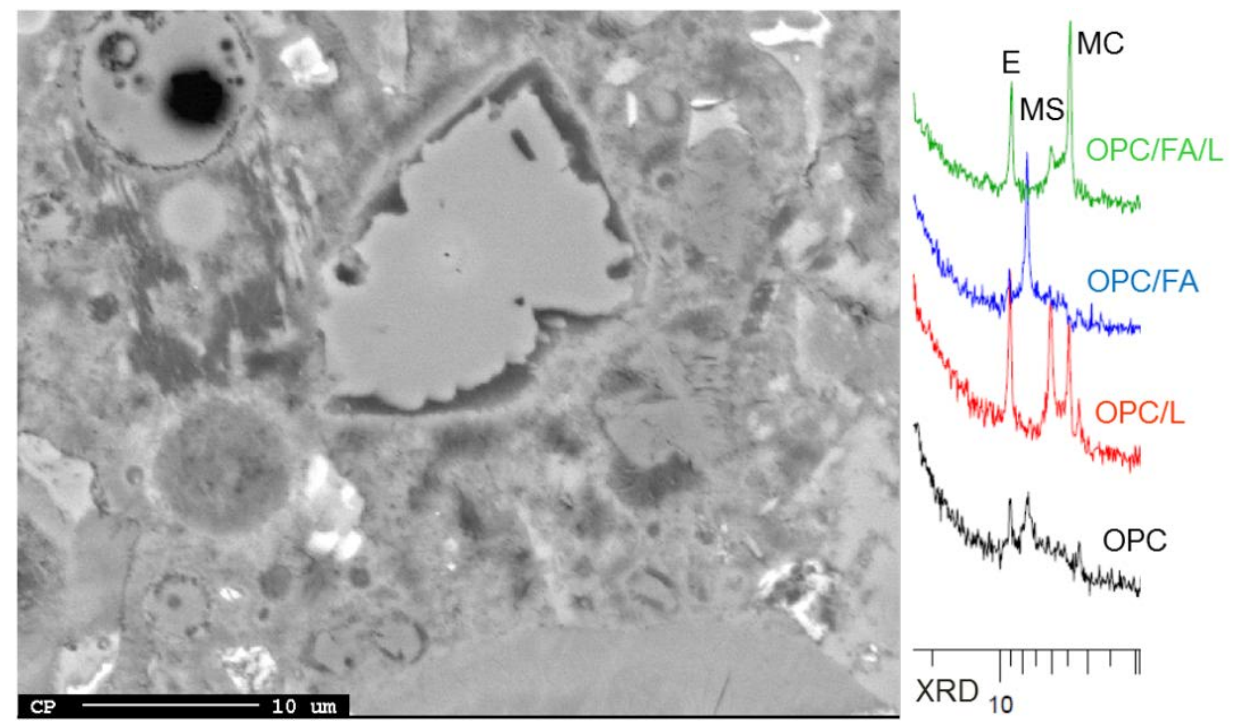

Figure 2 Left: BSE of paste consisting of cement/fly ash/limestone showing boundaries of a partly reacted limestone in the centre and a circular fly ash particle in the upper left. Right: Segments of XRD profiles for OPC with combinations of fly ash (FA) and limestone (L). OPC alone gives a mixture of ettringite (E) and monosulphate (MS). OPC/L stabilises E and form hemicarbonate and monocarbonate (MC). OPC/FA destabilises $E$ and form MS. OPC/FA/L stabilises $E$ and forms mainly MC.

It is of course not only fly ash that will form aluminates having a synergistic reaction with limestone, but also GGBS and calcined clay [Antoni et al., 2012] or marl. Fig. 3 (photo to the left) shows a BSE image of a mortar where $35 \%$ of cement has been replaced with calcined marl, and the formation of CAH in the centre of the image. A wave length dispersive spectrum (WDS) revealed the composition $16.5 \mathrm{Ca}, 8.3 \mathrm{Al}$ and $0.4 \mathrm{Fe}$ in atom\% (mark of electron beam can be seen), giving $\mathrm{Ca} / \mathrm{Al}=2.0$, so it is $\mathrm{C}_{4} \mathrm{ACH}_{11}$. [Justnes and Østnor 2014a]. The segment of XRD to the right in Fig. 3 reveals the formation of $\mathrm{C}_{4} \mathrm{~A} \underline{\underline{C}} \mathrm{H}_{11}$, calcium carboaluminate hydrate, in a mixture of calcined marl and calcium hydroxide [Justnes and Østnor, 2014b].

Neither is it necessary to use limestone, $\mathrm{CaCO}_{3}$, as carbonate source, since dolomite, $\mathrm{CaMg}\left(\mathrm{CO}_{3}\right)_{2}$, will 
function as well and even lead to higher strength through formation of voluminous hydrotalcite; $\mathrm{Mg}_{6} \mathrm{Al}_{2} \mathrm{CO}_{3}(\mathrm{OH})_{16} \cdot 4 \mathrm{H}_{2} \mathrm{O}$, according to Zajac et al. [2014].

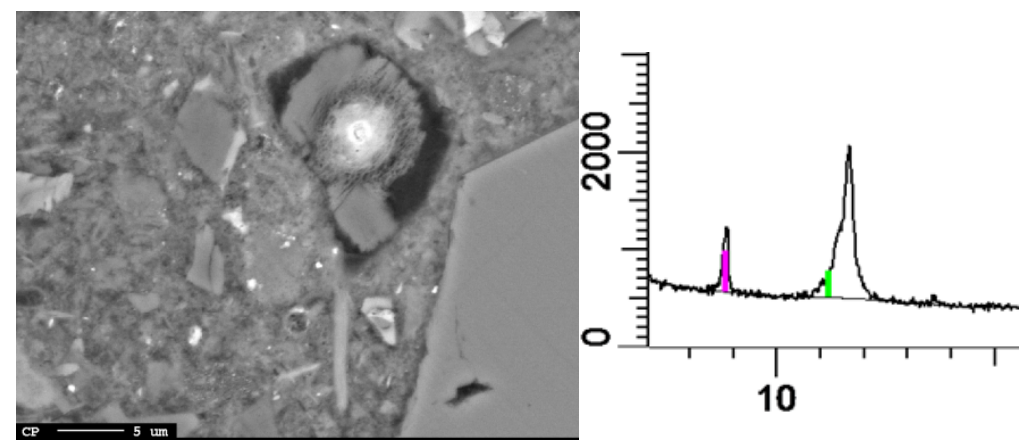

Figure 3 Left; BSE image of mortar where $35 \%$ cement is replaced with calcined marl and a CAH is formed in a void [Justnes and Østnor, 2014a]. Right; XRD segment of a paste of calcined marl mixed with lime showing an illite peak (clay mineral) at $2 \theta \approx 8.7^{\circ}$ and a peak from calcium monocarboaluminate hydrate at $2 \theta \approx 11.7^{\circ}$ [Justnes and Østnor 2014b].

\section{INCREASING REACTIVITY OF BLENDED CEMENTS BY ACCELERATORS}

SCMs react in general slower than cement. Both GGBS and FA are activated by increased $\mathrm{pH}$, but while GGBS is a latent hydraulic material, FA is a pozzolanic material consuming calcium hydroxide in producing hydraulic binder.

One advantage of using common potassium carbonate $\left(\mathrm{K}_{2} \mathrm{CO}_{3}\right.$ or $\mathrm{KC}$ in short) or sodium carbonate $\left(\mathrm{Na}_{2} \mathrm{CO}_{3}\right.$ or $\mathrm{N} \underline{C}$ in short) as fly ash or slag activator, is that they are safe to handle and will form high $\mathrm{pH}$ in situ by reaction with calcium hydroxide from cement hydration;

$\mathrm{CH}+\mathrm{K} \underline{\mathrm{C}}=\mathrm{C} \underline{\mathrm{C}}+\mathrm{KH}$

and at the same time form calcium carbonate with high surface area that probably is faster reactive with calcium aluminate hydrates than limestone powder. Such in situ forming accelerators were utilized by Justnes [1995] making lime-pozzolan mortars with high early strength. The disadvantage may be that alkali carbonates may retard the setting of cement and/or give somewhat lower long term strength depending on total alkali content.

Sodium sulphate is also a good accelerator for aluminate containing pozzolana and slag involving in situ formation of $\mathrm{NaOH}$ (short hand notation $\mathrm{NH}$ ) for further acceleration and formation of solid ettringite and/or monosulphate with increased water binding;

$3 \mathrm{~N} \underline{\mathrm{S}}$ (low pH) $+3 \mathrm{CH}$ (from cement) $+\mathrm{C}_{3} \mathrm{AH}_{6}$ (from pozzolan) $+26 \mathrm{H}=$

$3 \mathrm{NH}$ (high $\mathrm{pH})+\mathrm{C}_{6} \mathrm{AS}_{3} \mathrm{H}_{32}$

Shi and Day [1995, 2000a,b and 2001] studied the effect of $\mathrm{Na}_{2} \mathrm{SO}_{4}$ and $\mathrm{CaCl}_{2}$ as chemical activators on the strength of lime-fly ash pastes. ASTM type C and F fly ashes were used in the $20 \%$ hydrated lime and $80 \%$ fly ash mixes (no cement) and the chemical activators were added in dosages up to $5 \%$ of the limefly ash mass. The pastes were prepared with a water/solid ratio of 0.35 for type $\mathrm{F}$ or 0.375 for type $\mathrm{C}$ fly ashes, and cured moist at $50^{\circ} \mathrm{C}$. Both $\mathrm{Na}_{2} \mathrm{SO}_{4}$ and $\mathrm{CaCl}_{2}$ clearly increased the compressive strength of the mortars, but sodium sulphate was superior with respect to the 1 day strength. Unfortunately are many chemical activation experiments performed at elevated temperatures being irrelevant for ready mix 
concrete, but still applicable for precast concreting.

Shi and Day [1995] used X-ray diffraction (XRD) and scanning electron microscopy (SEM) to examine pastes with and without activators. The low lime fly ash (ASTM type F) without any activator had a CSHlike phase as principal hydration product, and the second major hydration product was found to be $\mathrm{C}_{4} \mathrm{AH}_{13}$. Minor products detected were ettringite (AFt) at early age and $\mathrm{C}_{2} \mathrm{ASH}_{8}$ at later age. The addition of sodium sulphate resulted in an increase of the $\mathrm{AFt}$ phase and a decrease in the $\mathrm{C}_{4} \mathrm{AH}_{13}$ phase, which is in line with reaction 9. Calcium chloride activator lead to formation of the solid solution $\mathrm{C}_{4} \mathrm{AH}_{13}-$ $\mathrm{C}_{3} \mathrm{~A} \cdot \mathrm{CaCl}_{2} \cdot 10 \mathrm{H}_{2} \mathrm{O}$.

Qian et al. [2001] compared the effect of grinding for 30 minutes in a ball mill and chemical activation through the addition of 3-4\% $\mathrm{Na}_{2} \mathrm{SO}_{4}$. They found that chemical activation was more efficient than ordinary grinding. Chemical activation increased the 3 and 7 day-strength of cement replaced with $30 \%$ fly ash by 5-10 MPa.

Lee et al. [2003] studied the strength and microstructure of fly ash-cement systems containing the accelerators $\mathrm{Na}_{2} \mathrm{SO}_{4}, \mathrm{~K}_{2} \mathrm{SO}_{4}$ and triethanolamine. The accelerators increased the amount of ettringite at early ages. The authors concluded that accelerators were a viable solution to increase early compressive strength of concrete with high amounts of fly ash.

High dosages of alkaline salts as accelerators may give lower long term strengths and may also be negative in terms of alkali-aggregate reactions (AAR). Another approach is to boost the cement reactivity rather than the SCM reactivity. Hoang [2012] investigated accelerators for mortars where cement was replaced with $30 \%$ fly ash. He arrived at a ternary accelerator based on $0.2 \%$ sodium thiocyanate (NaSCN), $0.1 \%$ diethanolamine (DEA) and $0.05 \%$ glycerol and showed that a $0.35 \%$ dosage of this ternary accelerator gave same improved strength after 2 days at $5^{\circ} \mathrm{C}$ as $4 \%$ sodium sulphate $\left(\mathrm{Na}_{2} \mathrm{SO}_{4}\right)+$ $0.4 \%$ NaSCN (total 4.4\%, more than 12x increased dosage), but the 28 days strength was higher for the low dosage of ternary accelerator. The ternary accelerator also fulfilled the requirements to a hardening accelerator according to EN 934-2 [2009] at a $0.35 \%$ dosage with $+60 \% 2$ day strength at $5^{\circ} \mathrm{C}$ and $+30 \%$ 1 day strength at $20^{\circ} \mathrm{C}$ relative to reference and was patented [Hoang, 2013].

\section{RHEOLOGY OF BLENDED CEMENTS}

Cement blended with SCMs with substantially higher specific surface than cement, and in particular irregular particles shapes with voids, leads to inferior rheology compared to ordinary cement. Justnes and $\mathrm{Ng}$ [2014] published a review on the influence of all components of a concrete matrix (i.e. cement type, SCMs and mineral fillers). Some information for the individual SCMS are repeated in the respective subsections.

\section{Silica fume}

Vikan and Justnes [2007] made cement pastes with a constant total particle volume of 0.442 corresponding to w/c about 0.40 as basis, while the amount of silica fume (SF) was replacing cement in volume increments of 0.01 from 0.00 to 0.06 . They concluded that the influence of SF replacement on the flow resistance (FR) depended on the plasticizer type: FR increased with increasing SF replacement when naphthalene sulphonated - formaldehyde condensate (NSF) was added as a plasticizer and decreased when polycarboxylic ether (PCE) was added. Increased FR and gel strength with SF replacement using SNF may be caused by early gel formation due to water binding by SF or the ionization of SF surface due to the high $\mathrm{pH}$ and possible bridging with polyvalent cations like calcium. Decreased FR with increasing SF replacement using PCE was explained by the dispersing power of PCE coupled with SF packing between cement grains displacing water or by a ball-bearing effect of silica spheres. 


\section{Fly ash}

Ng and Justnes [2014b] studied cementitious paste where OPC were replaced by siliceous fly ash (FA) in increments of 20 to $60 \%$ by mass and with a constant water-to-powder ratio of 0.36 . They investigated the effect of 5 plasticizers; lignosulfonate (LS), NSF and 3 PCEs. Some results are presented here, but Ng and Justnes, 2014a have presented detailed results for one PCE. The flow resistance (FR) decreased steadily with increasing replacement of OPC by FA as shown in Fig. 4 in spite of increased total volume of solids since the density of FA is lower than OPC. The decrease in FR is due to the spherical nature of FA and the low reactivity of the glass phase at this early stage. Furthermore, there is much lower interaction of the plasticizers with FA than with cement, so the effective plasticizer-to-cement ratio is increasing and thereby also the retardation of the cement as illustrated in Fig. 5 for NSF.

Investigations on admixture interactions with cement blended with ground blast furnace slag are limited. Blast furnace slag consists of a glass phase with in the order of $40 \% \mathrm{CaO}$. The surface is believed to have calcium-sites capable of coordinating with plasticizers unlike the glassy phase of siliceous fly ash in subchapter 5.2, but still to a smaller extent than for OPC.

Palacios et al. [2009] studied the effect of a number of plasticizers on the yield stress and plastic viscosity of alkali activated slag (AAS) and OPC pastes. They concluded that the adsorption of the plasticizers on AAS pastes was independent of the $\mathrm{pH}$ of the alkaline solutions used and lower than on OPC pastes. However, the effect of the admixtures on the rheological parameters depended directly on the type and dosage of plasticizer as well as of the binder used and, in the case of the AAS, on the $\mathrm{pH}$ of the alkaline activator solution. In 11.7-pH NaOH-AAS pastes the dosages of plasticizers required to attain similar reduction in the yield stress were ten-fold lower than for Portland cement. For this $\mathrm{pH}$ the plasticizers showed a fluidizing effect considerably higher than in OPC pastes. In 13.6-pH NaOH-AAS pastes, the only plasticizer to affect the rheological parameters was NSF due to its higher chemical stability in such extremely alkaline media.

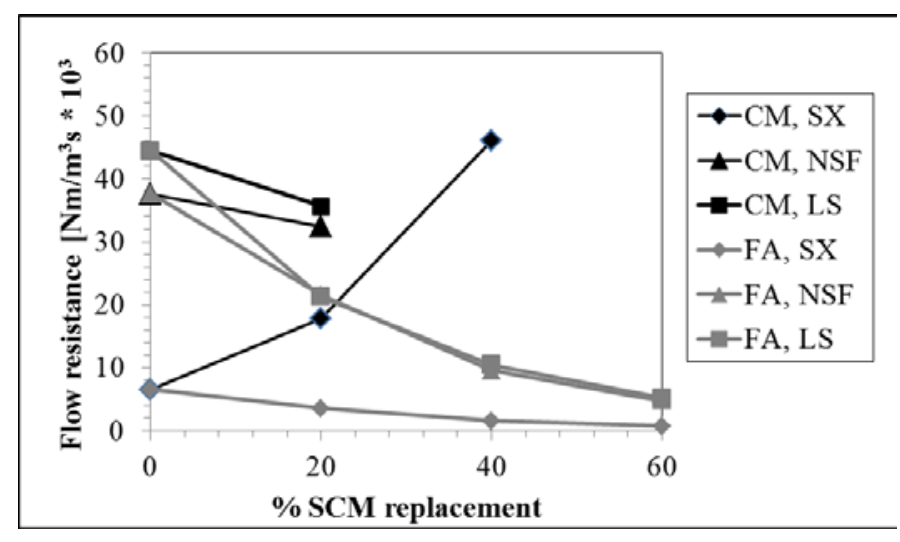

Figure 4 Flow resistance as a function of OPC replacement by SCM, fly ash (FA) or calcined marl (CM) with $0.2 \%$ dry plasticizer LS, NSF and a PCE named SX) of powder mass.

\section{Calcined clay}

Ng and Justnes [2014b] studied also cementitious paste where OPC were replaced by calcined marl (CM) in increments of 20 to $60 \%$ by mass and with a constant water-to-powder ratio of 0.36 . They investigated the effect of the same 5 plasticizers; LS, NSF and 3 PCEs as for FA in section 5.2. The flow resistance 
(FR) plotted in Fig. 4 shows that it decreased slightly from 0 to $20 \%$ OPC replacement by CM and $0.2 \%$ addition of dry plasticizer for LS and NSF. Workable mixes were not attained for these plasticizers at a $0.2 \%$ dosage for higher CM replacements. For 0.2\% PCE (SX) addition, FR increased with increasing OPC replacement by CM until $40 \%$, while the $60 \%$ was not workable at this PCE dosage. Reasons for lower workability when OPC is replaced by CM are higher volume of solid due to lower density, higher water absorption by its porous nature and less reactive surface with less calcium sites than OPC. CM surface is assumed to be more reactive and have more Ca-sites then siliceous fly ash (FA) and adsorb more plasticizer. This is also reflected in the heat of hydration evolution curves when OPC is replaced with CM using NSF leading to acceleration rather than retardation for the FA replacement as seen in Fig. 5. This indicates that the effective plasticizer-to-cement ratio is less in the case of CM replacement than for FA replacement.

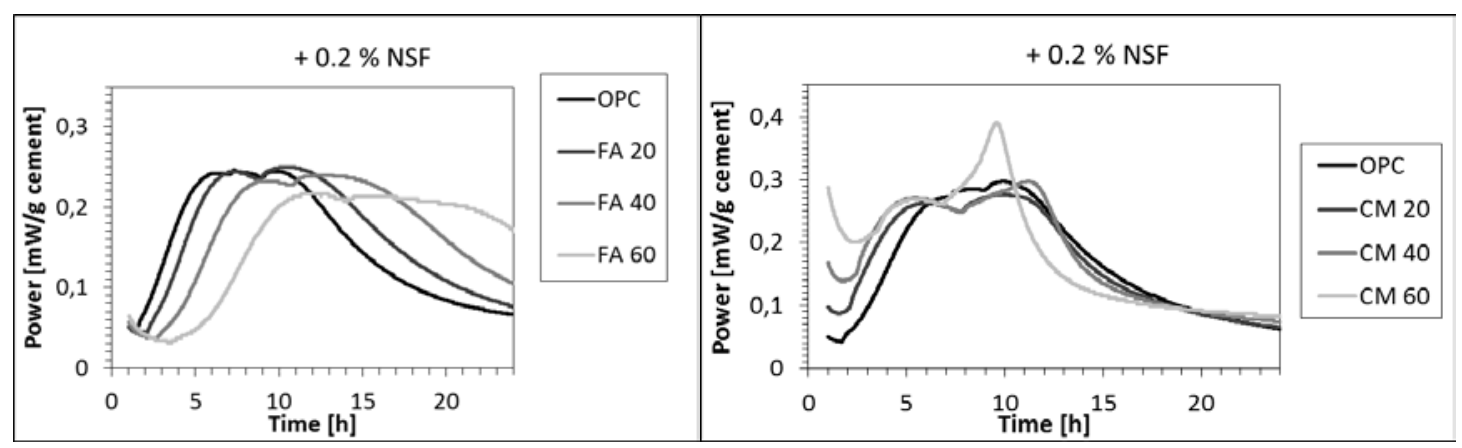

Figure 5 Heat of hydration (Power) evolution per cement mass for cementitious pastes with 0 (OPC), 20 (FA20), 40 (FA40) and 60\% (FA60) replacement of OPC with FA to the left and with 0 (OPC), 20 (CM20), 40 (CM40) and 60\% (CM60) replacement of OPC with CM to the right. All pastes are plasticized by $0.2 \%$ dry NSF of powder mass.

\section{INFLUENCE OF SCMS ON DURABILITY OF BLENDED CEMENTS}

There is a general dilemma in all accelerated durability testing: How can the exposure be sufficiently accelerated in order to give in a relative short time the same environmental load as a long-term natural exposure? This is usually sought achieved my increasing the exposure temperature (e.g. alkali aggregate reactions) or by increasing the concentration of the aggressive component (e.g. carbonation).

Increased temperature prior to exposure is also often used to achieve a more mature cementitious binder since SCMs often react much slower than the cement hydrate at ambient temperature and many of the degradation mechanisms happens slowly over years. However, it is important to not raise the temperature so high that changes occur in the binder that will not happen in practice. For instance it is well known, that the CSH gel becomes coarser and more porous already at $50^{\circ} \mathrm{C}$ [Kjellsen et al, 1990a,b and 1991] and fly ash/lime mixes might have a phase change when cured at $38^{\circ} \mathrm{C}$ relative to $20^{\circ} \mathrm{C}$ [De Weerdt and Justnes, 2008]. Another example is paste where cement is partly replaced by calcined clay as SCM and cured at $38^{\circ} \mathrm{C}$ [Danner, 2012] where dense areas of the hydrogarnet katoite formed and not seen at $20^{\circ} \mathrm{C}$.

\section{Chloride ingress}

Chloride ingress is not detrimental to the binder itself, but may induce corrosion of reinforcement steel in spite of high $\mathrm{pH}$ when exceeding a certain threshold value of chloride at the steel surface. The required total chloride content at the rebar to initiate corrosion is often taken as $0.1 \% \mathrm{Cl}^{-}$of concrete mass irrespectively of the binder type. Chloride binding is not taken into account even though it is the chlorides in the pore water next to the steel that are destabilizing the protective oxide layer created by the high $\mathrm{pH}$. 
Many refer to a certain $\mathrm{Cl}^{-} / \mathrm{OH}^{-}$ratio in order to initiate steel corrosion, but the values scatter. The following conclusions were made from a state-of-the-art report on critical chloride level [Angst and Vennesland, 2007]; "A lot of studies have been undertaken in the context of critical chloride content and the published results scatter in a wide range. The reported results span from 0.02 to $3.08 \%$ total chloride by weight of binder and thus over two orders of magnitude. Published $\mathrm{Cl}^{-} / \mathrm{OH}^{-}$ratios even range from 0.03 to 45 and thus over three orders of magnitude.”

Even though pozzolanic SCMs consume calcium hydroxide $(\mathrm{CH})$, the remaining $\mathrm{CH}$ will buffer $\mathrm{pH}$ to 12.5, albeit it may be reduced from $\mathrm{pH} 13.2$ given by the alkali hydroxides as long as SCM prevails. Alumina containing SCMs may in addition form CAH that will lead to increased chemical binding of chlorides as Friedel's salt; $\mathrm{Ca}_{3} \mathrm{Al}_{2} \mathrm{O}_{6} \cdot \mathrm{CaCl}_{2} \cdot 12 \mathrm{H}_{2} \mathrm{O}$, as well as increased adsorption on CSH-gel as more gel is formed on the expense of $\mathrm{CH}$ in the pozzolanic reaction. Thus, it is difficult to judge how SCMs will affect the $\mathrm{Cl}^{-} / \mathrm{OH}^{-}$ratio. If properly dispersed, SCMs will in general also refine the porosity of the binder and reduce the diffusion rate of aggressives as chloride.

An example of chloride ingress profiles in mortars with increasingly volume replacement of cement by calcined marl is shown in Fig. 6 [Justnes and Østnor, 2014a] revealing that chloride ingress is substantially reduced up to a cement replacement of $50 \mathrm{vol} \%$. Such profiles of total chloride content is often erroneously [Justnes and Geiker, 2012] used to be fitted to solutions of Fick's $2^{\text {nd }}$ law of diffusion to yield a surface concentration of chlorides and an apparent diffusion coefficient that is further used in service life modelling of concrete structures, even though it is only the free chlorides that are moving. Another benefit of SCMs is increased electrical resistivity as exemplified in Fig. 7 for the same mortars as in Fig. 6. A high electrical resistivity brought about by a combination of porosity segmentation and reduced ion activity (i.e. hydroxyl ions are the most important charge carriers) in the pore fluid, may also reduce corrosion rate of steel once it is initiated.

Fidjestøl and Justnes [2004] investigated the chloride profiles in a quay structure in Gothenburg harbor after 24 years of service. The water in the harbor is partly brackish with an average chloride concentration of $1.4 \%$ as opposed to $1.9 \%$ in Atlantic waters. The quay was cast with different segments of concrete with $5 \%$ silica fume and without, and if the chloride profiles are fitted to the solution of Fick's $2^{\text {nd }}$ law of diffusion it resulted in apparent diffusion coefficients of 0.32 and $0.90 \cdot 10^{-12} \mathrm{~m}^{2} / \mathrm{s}$ for $5 \%$ and $0 \%$ silica fume, respectively.

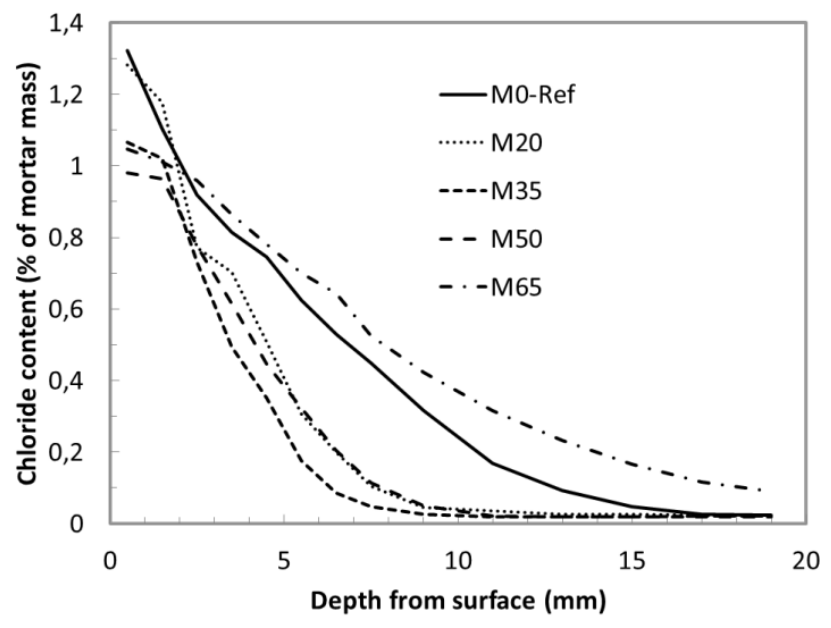

Figure 6 Chloride ingress in mortars where cement is replaced with 0 (M0), 20 (M20), 35 (M35), 50 (M50) and 65 (M65) vol\% calcined marl after exposure for 35 days to $165 \mathrm{~g}$ $\mathrm{NaCl} /$ liter [Justnes and Østnor, 2014a]. 


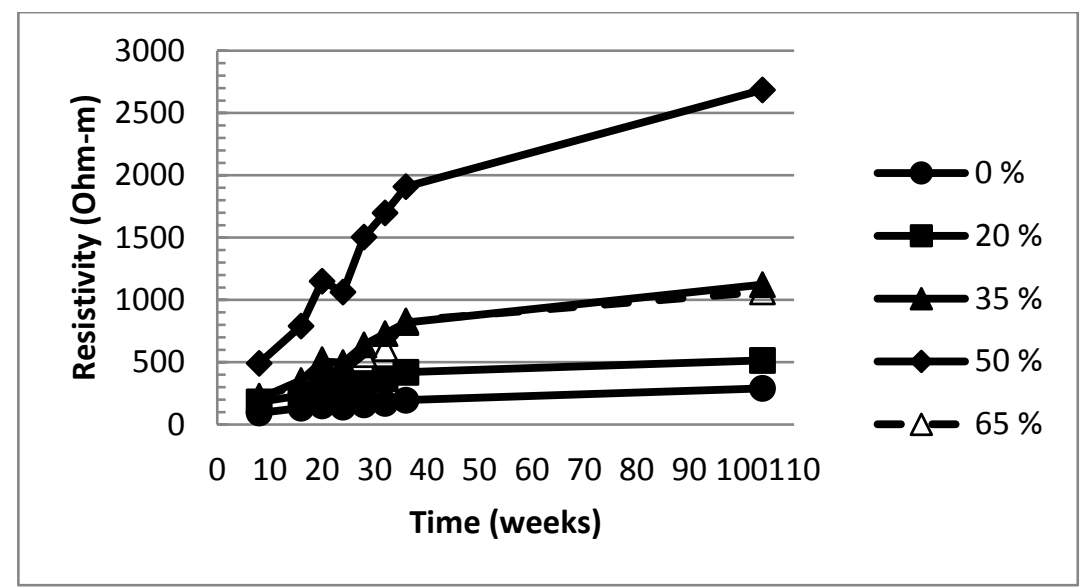

Figure 7 Resistivity of mortars where cement is replaced with calcined marl from 0-65 vol\% as a function of time.

Thomas and Bamforth [1999] investigated the effect of cement replacement by $30 \%$ fly ash or $70 \%$ GGBS on chloride ingress in concrete blocks naturally exposed to seawater spray over a period of several years with the objective of finding the decay coefficient (m) of the apparent diffusion coefficient in Eq. 10 ;

$$
D_{t}=D_{\text {ref }}\left(t_{\text {ref }} / t\right)^{m}
$$

\section{where}

$\mathrm{D}_{\mathrm{t}}=$ apparent diffusion coefficient at time $\mathrm{t}$

$\mathrm{D}_{\text {ref }}=$ apparent diffusion coefficient at a given reference time, e.g. 28 days

$\mathrm{m}=$ decay coefficient

Thomas and Bamforth [1999] found $\mathrm{D}_{28 \mathrm{~d}}=8,6$ and $25 \cdot 10^{-12} \mathrm{~m}^{2} / \mathrm{s}$ for reference, $30 \mathrm{FA}$ and $70 \%$ GGBS, respectively, with corresponding values $\mathrm{m}=0.1,0.7$ and 1.2. In spite of higher $\mathrm{D}_{28 \mathrm{~d}}$, the accumulated chloride ingress in concrete with 30\% fly ash or 70\% GGBS was about equal but much lower than reference after 2 years and onwards to 8 years. This illustrates the importance of mature samples with high dosages of SCMs prior to accelerated exposure.

Sometimes ternary mixes are beneficial, as shown by Thomas et al. [1999] where cement replaced by 25\% FA and $8 \%$ SF resulted in lower chloride ingress than either component alone, probably by a combination of improved particle packing and increased reactivity.

\section{Carbonation}

Carbonation is actually a neutralization reaction between carbonic acid, $\mathrm{H}_{2} \mathrm{CO}_{3}$ (i.e. $\mathrm{CO}_{2}$ dissolved in water) and alkaline components in the blended cement;

$$
\begin{aligned}
& 2 \mathrm{NaOH}+\mathrm{H}_{2} \mathrm{CO}_{3}=\mathrm{Na}_{2} \mathrm{CO}_{3}+2 \mathrm{H}_{2} \mathrm{O} \\
& \mathrm{Ca}(\mathrm{OH})_{2}+\mathrm{H}_{2} \mathrm{CO}_{3}=\mathrm{CaCO}_{3}(\mathrm{~s})+2 \mathrm{H}_{2} \mathrm{O} \\
& \mathrm{Ca}_{3} \mathrm{Si}_{2} \mathrm{O}_{7} \cdot 4 \mathrm{H}_{2} \mathrm{O}(\mathrm{s})+\mathrm{H}_{2} \mathrm{CO}_{3}=\mathrm{CaCO}_{3}(\mathrm{~s})+\mathrm{Ca}_{2} \mathrm{Si}_{2} \mathrm{O}_{6} \cdot \mathrm{xH}_{2} \mathrm{O}+(5-\mathrm{x}) \mathrm{H}_{2} \mathrm{O}
\end{aligned}
$$


According to Engelsen and Justnes [2014], all hydrates formed by cement will carbonate, but CSH will probably only carbonate down to a $\mathrm{Ca} / \mathrm{Si}$ of about 1 . Based on stoichiometric considerations they calculated that about $72 \%$ of all $\mathrm{CaO}$ in an ordinary portland cement will carbonate. Visser [2014] recently reviewed carbonation mechanisms and consequences of elevated $\mathrm{CO}_{2}$ concentrations for accelerated testing. Carbonation reduces $\mathrm{pH}$ of the pore water from about 13 to around 9 and the carbonation front inwards is easily detected by spraying an indicator like phenolphthalein on a broken surface since it is colorless for $\mathrm{pH}<10$ and pink above. The carbonation front is also believed to be relatively steep.

There are basically 2 reasons why cements blended with SCMs are more prone to carbonation than ordinary portland cements; 1 ) the physical thinning effect since there is less cement per volume unit to produce calcium hydroxide and 2) the chemical pozzolanic effect of some SCMs consuming calcium hydroxide. The question is whether or not their hydration products will carbonate as they tend to produce $\mathrm{CSH}$ of low $\mathrm{C} / \mathrm{S}$ less prone to carbonation under natural conditions $\left(\approx 0.04 \% \mathrm{CO}_{2}\right)$ even though they might carbonate at $\geq 1 \% \mathrm{CO}_{2}$.

The water-to-cement ratio (w/c) together with the amount and volume of hydration products determines the connectivity of pores and also the carbonation depth as shown in Fig. 8 for mortar where OPC is replaced by FA and GGBS as function of w/c and compared to OPC. It can be seen that a mortar with $17 \%$ replacement of cement by FA carbonates only slightly faster than for cement replaced with $48 \%$ GGBS at the same w/c. Thus, it seems to be controlled by total $\mathrm{CaO}$ in the system which is about $52 \%$ for both. Bernal et al. [2014] showed that for alkali-activated slags, the carbonation rate went down with increasing MgO content of the slags, probably due to the formation of hydrotalcite.

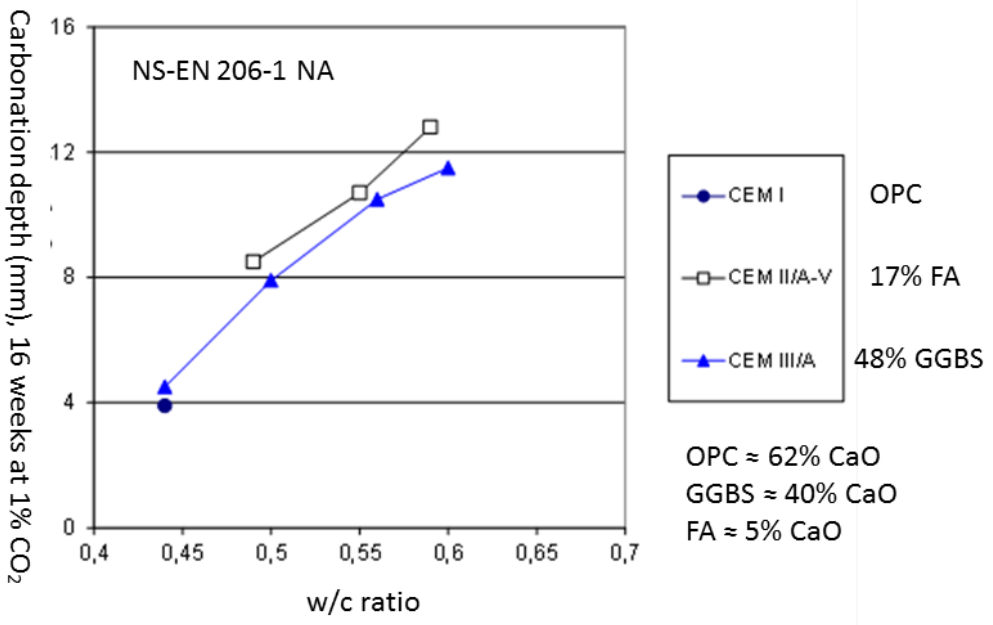

Figure 8 Carbonation depth $(\mathrm{mm})$ of mortar where cement has been replaced with $17 \%$ fly ash containing $\approx 5 \% \mathrm{CaO}$ or $\mathbf{4 8 \%}$ GGBS containing $\approx \mathbf{4 0} \% \mathrm{CaO}$ as a function of w/c and compared to reference OPC containing $\approx 62 \% \mathrm{CaO}$ after exposure for 16 weeks to $1 \% \mathrm{CO}_{2}$ at $60 \% \mathrm{RH}$ and $20^{\circ} \mathrm{C}$. Samples preconditioned 28 days under water and 14 days at $50 \%$ RH.

Justnes and Østnor [2014a] tested the carbonation rate of mortars with increasing volume replacement of cement by calcined marl and constant water-binder ratio for carbonation depth versus square root of time. Such a plot is expected to be linear if diffusion controlled, but in this case it is curved for replacement levels $\geq 35 \mathrm{vol} \%$. This might be due to rapid pozzolanic reaction forming $\mathrm{CSH}$ of low $\mathrm{C} / \mathrm{S}$ that will not carbonate. Calcined clay/marl reacts much faster than for instance fly ash. 
Generally speaking, the carbonation rate will increase with increasing SCM at constant w/c and curing time. However, when the concrete is proportioned to give same 28 days strength, the carbonation rate seems to be similar irrespectively of SCM according to Thomas [2013]. Studies that employ enriched $\mathrm{CO}_{2}$ to accelerate carbonation tend to overestimate the carbonation rate in concrete with SCMs [Thomas et al, 2000]. Drawing conclusions from short-term tests (< 5 years) may overestimate the negative impact of fly ash on carbonation rates in concrete [Hobbs, 1986].

\section{Alkali aggregate reactions}

Alkali aggregate reactions (AAR) are most often caused by dissolution of reactive silica in the aggregate by alkali hydroxides in the pore solution, which turn into a viscous, swelling gel when it meets the paste binder and alkalis partly ion exchange with calcium.

Replacing cement with SCMs generally reduce expansion due to AAR [Thomas, 2011]. This has in general been thought to be caused by a reduction in $\mathrm{pH}$ (i.e. hydroxyl concentration) of pore water and a lower content of calcium hydroxide. In the author's opinion, the reduction in $\mathrm{pH}$ will be the case as long as the alkalis are busy in dissolving SCM in the catalytic way outlined in Eq. 3, but the implication is that this may cause only a delay of AAR until the SF has reacted totally. Bérubé and Duchesne [1992] showed indeed that SF merely postpones expansion due to AAR. Nevertheless, SF as a preventative against AAR, together with other improvements in construction procedures, has found its application in Iceland where all cement has been interground with 7-8 \% SF to combat the problem [Asgeirsson, 1986]. Fournier et al. [2004] also showed that $>7 \%$ SF was able to control ASR.

According to Thomas [2013] the level of cement replacement by SCM required to control AAR expansion increases as 1) $\mathrm{SiO}_{2}$ content of SCM decreases, 2) $\mathrm{CaO}$ of SCM increases, 3) alkali content of SCM increases, 4) alkali availability in the concrete increases and 5) reactivity of the aggregate increases. Shehata and Thomas [2000] showed that low calcium fly ashes (ASTM Class F) are much more effective in reducing AAR expansion (typical cement replacement level $>20 \%$ ) than high calcium fly ashes (ASTM class C). Shehata and Thomas [2002] demonstrated that the required level of low calcium fly ash could be reduced to $10 \%$ when combined with $5 \%$ SF as a ternary blend. Thomas and Innis [1998] found that North American GGBS at a cement replacement level of $>40 \%$ was able to control expansion caused by AAR. Bleszynski et al. [2002] showed that GGBS in combination with SF as a ternary blend including cement was better than GGBS replacement alone in reducing AAR expansion. Ramlochan and Thomas [2000] proved that highly reactive metakaolin at a cement replacement level $>10 \%$ was able to combat expansion due to AAR.

Some have suggested that the presence of alumina in SCMs contributes to prevent the release of alkali back to the pore solution by binding in the hydration products. However, Chappex and Scrivener [2012a] showed that this effect is extremely small, and instead it was found that alumina is an inhibitor of silica dissolution [Chappex and Scrivener, 2012b and 2013] in their system with metakaoline as SCM. Favier et al. [2014] showed that AAR is prevented by calcined clay mixed with limestone as well.

\section{Sulphate attack}

There are 2 forms of sulphate attack; 1) external where sulphates from the surroundings are penetrating the hardened concrete forming expanding ettringite and 2) internal that can be caused by decomposition of ettringite during hot curing exceeding $70^{\circ} \mathrm{C}$ and later reformation and expansion after cooling (i.e. delayed ettringite formation shortened DEF). A special form of external sulphate attack can occur at low temperatures $\left(<15^{\circ} \mathrm{C}\right)$ if the concrete contains limestone, namely the formation of thaumasite; $\mathrm{Ca}_{3} \mathrm{Si}(\mathrm{OH})_{6}\left(\mathrm{CO}_{3}\right)\left(\mathrm{SO}_{4}\right) \cdot 2 \mathrm{H}_{2} \mathrm{O}$, that can take silicate from the CSH and turn it into a non-binding mush [Irassar, 2009). A special form of internal sulphate attack is from aggregate containing iron sulfides that 
may oxidize to sulphates [Duchesne, 2012].

The good performance of concrete with SCMs in a sulfate environment can be attributed to several factors of which the most important are likely to be i) the refined pore structure and thus reduced mobility of harmful ions and ii) the lower calcium hydroxide content by thinning or pozzolanic reaction and iii) formation of more CAH that will at least delay formation of AFt since AFm must form first. The second factor leads to reduced formation of expansive gypsum (Eq. 14) and later ettringite from, for instance, calcium aluminate hydrates (Eq. 15) or monosulfate, AFm (Eq. 16), found in the hydrated concrete binder.

$$
\begin{aligned}
& \mathrm{Ca}(\mathrm{OH})_{2}(\mathrm{~s})+2 \mathrm{H}_{2} \mathrm{O}+\mathrm{SO}_{4}{ }^{2-}=\mathrm{CaSO}_{4} \cdot 2 \mathrm{H}_{2} \mathrm{O}(\mathrm{s})+2 \mathrm{OH}^{-} \\
& \mathrm{C}_{3} \mathrm{AH}_{6}(\mathrm{~s})+3 \mathrm{CS}_{2}(\mathrm{~s})+20 \mathrm{H}=\mathrm{C}_{6} \mathrm{~A}_{3} \mathrm{H}_{32}(\mathrm{~s}) \\
& \mathrm{C}_{4} \mathrm{AS}_{12}(\mathrm{~s})+2 \underline{\mathrm{C}}_{\mathrm{H}}(\mathrm{s})+16 \mathrm{H}=\mathrm{C}_{6} \mathrm{~A}_{3} \mathrm{H}_{32}(\mathrm{~s})
\end{aligned}
$$

Based on molar volumes, it can be calculated that the reaction in Eq. 14 leads to 124\% expansion of the solid (s). The reaction in Eq. 15 leads to $371 \%$ increase relative to the $\mathrm{C}_{3} \mathrm{AH}_{6}$ crystal (localized growth) or $89 \%$ relative to both $\mathrm{C}_{3} \mathrm{AH}_{6}$ and gypsum, while the reaction in Eq. 16 leads to $128 \%$ expansion relative to the AFm phase only (localized growth) or $54 \%$ expansion relative to both AFm and gypsum. These expansive reactions result in cracking and spalling if the stress exceeds the tensile strength of the binder. Scrivener [2012] pointed out that ettringite needs to be supersaturated in order to create a pressure leading to expansion. Müllauer et al. [2012] studied sulfate attack mechanisms in detail.

When SF is used together with GGBS or FA as cement replacement [Carlsen and Vennesland, 1980, and Fidjestøl and Frearson, 1994] these ternary mixtures have been found to be more resistant to sulfate attack than special sulfate resisting cements.

Kunther et al. [2013] showed an improvement of the sulphate resistance (50 $\mathrm{g} \mathrm{Na}_{2} \mathrm{SO}_{4}$ /liter)for a cement with 70\% GGBS relative to an OPC, and also that the expansion due to sulphate attack was substantially reduced when bicarbonate was present simultaneously (50 g $\mathrm{Na}_{2} \mathrm{SO}_{4}+30$ g $\mathrm{NaHCO}_{3} /$ liter). They explained the latter effect by ettringite and gypsum becoming unstable in presence of bicarbonate and that the ettringite could not build up the crystallization pressure required to create expansion. An alternative explanation is that $\mathrm{CO}_{3}-\mathrm{AFm}$ is more stable than $\mathrm{SO}_{4}$-AFm and would prevent $\mathrm{AFt}$ formation.

Dehwah [2007] exposed concrete specimen to $5 \% \mathrm{NaCl}$ and sodium sulphate of concentrations 1, 2.5 and $4 \%$ solutions for up to 4 years. The concretes were based on two types of cement (ASTM C150 type I and V), as well as cement type I replaced by $10 \%$ silica fume, $20 \%$ fly ash or $70 \%$ GGBS. None of the concretes showed any deterioration after 4 years, indicating that Friedel's salt (Cl-AFm) may be more stable than monosulphate $\left(\mathrm{SO}_{4}\right.$ - $\left.\mathrm{AFm}\right)$ at the experimental conditions.

Ghafoori et al. [2015] evaluated the sulfate resistance of concrete based on ASTM type V cement of different cement contents (and thereby w/c) when replaced with 0, 15, 20, 25 and 30\% ASTM class F (siliceous) fly ash. They found that the improvement in sulfate resistance was only modest (15\%) and that the required FA replacement increased with increasing cementitious content of the concrete.

Hossack and Thomas [2015] studied the sulfate resistance at both 5 and $23^{\circ} \mathrm{C}$ for mortars based on cements with limestone content varying from $4-22 \%$. In their series cement was partly replaced with fly ash (ASTM types C and F), blast furnace slag, silica fume or metakaolin, as well as some ternary blends thereof. They found that SCMs greatly improved the sulfate resistance at $23^{\circ} \mathrm{C}$, but higher SCM levels may be required when limestone is present. The greatest degree of resistance to sulphate attack was found 
with ternary mixes of silica fume with fly ash or blast furnace slag, as well as for high replacement levels of metakaolin. Ettringite, thaumasite and gypsum were found in all samples exposed to $\mathrm{Na}_{2} \mathrm{SO}_{4}$ at $5^{\circ} \mathrm{C}$ indicating a mixed form of sulfate attack.

Abdalkader et al. [2015] investigated sulphate attack on mortars based on cement and cement blended with $10 \%$ limestone exposed for combined action of chloride $\left(0,0.5,1\right.$ or $2 \% \mathrm{Cl}^{-}$and sulfate $\left(0.6 \% \mathrm{SO}_{4}{ }^{2-}\right)$ for 630 days at $5^{\circ} \mathrm{C}$. All specimens suffered from the thaumasite form of sulfate attack, with the exception of the combination of sulfate with $2 \% \mathrm{Cl}^{-}$. The degradation was more severe for samples with limestone. The better performance in combination with the highest chloride concentration was explained by increased Friedel's salt formation, possibly preventing ettringite formation that many think is a prerequisite for the formation of the isostructural thaumasite. Even though chloride may prohibit thaumasite formation it was still found in concrete with limestone filler exposed to sea water $\left(0.27 \% \mathrm{SO}_{4}{ }^{2-}\right.$ and $1.9 \% \mathrm{Cl}^{-}$) for 10 years outside Trondheim, Norway [De Weerdt and Justnes, 2014].

When it comes to the effect of SCMs on internal sulphate attack, Rønne et al. [1995] published the effect of SF on expansion due to delayed ettringite formation (DEF), and the measurements for 2 years are plotted in Fig. 9 for OPC with 0 and $8 \% \mathrm{SF}$ and $\mathrm{w} /(\mathrm{c}+\mathrm{SF})=0.40$. The concrete was resting for 6 hours before being heated to the set temperature of 20,70 or $85{ }^{\circ} \mathrm{C}$ with a rate of $12^{\circ} \mathrm{C} / \mathrm{h}$ in a water bath that thereafter cooled down slowly to the ambient temperature of $20^{\circ} \mathrm{C}$ to mimic the temperature evolution in a massive structure driven by heat of hydration. The rest of the curing time was at $20^{\circ} \mathrm{C}$ and the volume of the specimens was monitored by weighing in water and air according to the principle of Archimedes. SEM confirmed ettringite formation in aggregate interfaces and cracks for the expanding specimens.

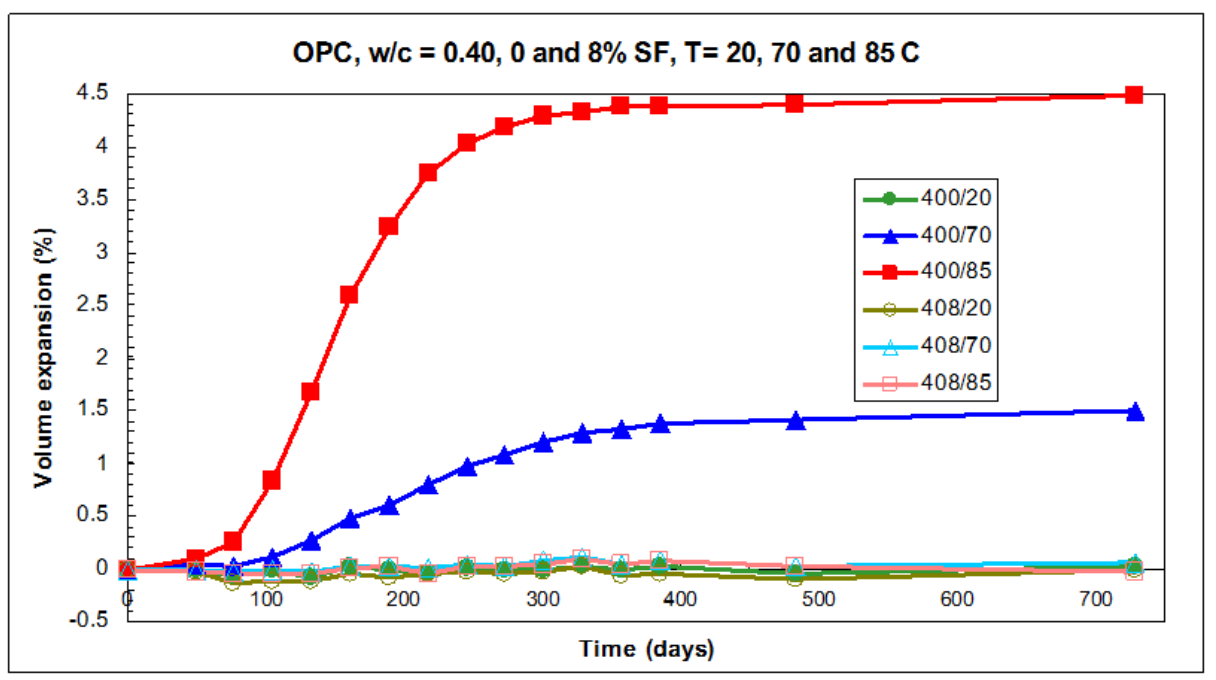

Figure 9 Volume changes of OPC concrete with w/cm $=0.40$ with $0 \%$ (legend 400 ) and $8 \%$ (legend 408) SF initial cured at 20, 70 and $85^{\circ} \mathrm{C}$ followed by $20^{\circ} \mathrm{C}$ water curing $>2$ years [Rønne et al, 1995].

Ramlochan et al. [2003, 2004] initial cured mortar samples at $95^{\circ} \mathrm{C}$ followed by storage in limewater at $23^{\circ} \mathrm{C}$ up to 1500 days. They found that $25 \%$ replacement of cement by SCMs containing alumina; such as fly ash (both ASTM class C and F), blast furnace slag and metakaolin, was able to prevent DEF while 8\% silica fume only had limited effect (expansion reached 1.0\% compared to reference expanding 2.8\%). 


\section{Freeze-thaw resistance}

Concrete with a high degree of capillary saturation with water $(>92 \%)$ can be damaged by repetitive freezing and thawing cycles (fatigue) since water expands 9\% upon freezing and can create a hydraulic pressure forcing unfrozen water into smaller pores leading to cracking. This is usually mitigated by entraining small air bubbles with the help of appropriate admixtures. These well distributed air bubbles are empty and will function as pressure relief chambers upon freezing. Concrete with SCMs is believed to be equal resistant to freeze-thaw as concrete with ordinary portland cement providing that a good air void system is obtained by the aid of air entraining agents and that the concrete is well cured. SCMs react slower than OPC and concrete with SCM is thus more sensitive to improper workmanship. There are indications that blended cement may be more sensitive to freeze-thaw under the influence of thawing salts like sodium chloride $(\mathrm{NaCl})$, and an interaction with aluminates forming Friedel's salt ca not be ruled out.

Residual carbon in fly ash is known to create a problem by adsorbing air entraining agents leading to the need of higher dosages to obtain a good air void system. This can also be omitted by adding sacrificial agents that will preferentially adsorb to the free carbon [Jolicoeur et al, 2009].

There have also been reports on concrete with high blast furnace slag content that become more prone to freeze-thaw damage under influence of thawing salts [Panesar and Chidiac, 2007; Giergiczny et al, 2009], and in particular when carbonated [Utgenannt, 2004]. A possible remedy against the inferior freeze-thaw resistance of concrete with GGBS seems to be surface treatment with sodium monofluorophosphate [Sisomphon et al, 2010].

\section{CONCLUSIONS}

Concrete based on cement blended with SCMs, or where ordinary cement is partly replaced with SCMs, is more durable in general than concrete based on ordinary portland cement at equal water-to-binder ratio, when well cured and when the SCM is properly dispersed. The main reasons are a denser microstructure either due to improved particle packing initially or more binder ( $\mathrm{CSH}$ or $\mathrm{CAH}$ ) formed on the expense of calcium hydroxide $(\mathrm{CH})$ either due to displacement of cement or pozzolanic reaction.

The exception is carbonation resistance which is increasing with increasing cement replacement by SCMs at equal water-to-binder ratio due to less $\mathrm{CH}$, even though most calcium containing components will carbonate in the end. However, the increased carbonation rate can be counteracted by reducing the waterto-binder ratio, but if this is achieved by increasing the binder content the positive effect of using $\mathrm{SCM}_{\mathrm{S}}$ for the sake of environment will be reduced.

Limestone can also be considered as a SCM, in particular in combination with other SCMs producing $\mathrm{CAH}$ that can be a reactant for a synergic reaction binding even more water that will help densifying the porosity of the binder.

The resistance to ingress of chemicals depends largely on the AFm phases in the binder and which one is the most stable. For instance is the binding of chlorides improved by the presence of CAH forming Friedel's salt and ingress is delayed.

\section{REFERENCES}

Abdalkader, A.H.M., Lynsdale, C.J. and Cripps, J.C., 2015. The effect of chloride on cement mortar subjected to sulfate exposure at low temperature. Construction and Building Materials, 78,102-111.

Angst, U. and Vennesland, Ø., 2007. COIN P4: Operational Service Life Design, SP 4.2: Critical chloride content. State-of-the-Art. SINTEF Report SBF BK A07037, 2007-12-17, 54 pp. 
Antoni, M., Rossen, J., Martirena, F and Scrivener, K., 2012. Cement substitution by a combination of metakaoline and limestone. Cement and Concrete Research, 42, 1579-1589.

Asgeirsson, H., 1986. Silica Fume in Cement and Silane for counteracting of Alkali-Silica Reactions in Iceland. Cement and Concrete Research, 16, 423-428.

Barbhuiya, S., Mukherjce, S. and Nikraz, H., 2014. Effects of nano- $\mathrm{Al}_{2} \mathrm{O}_{3}$ on early-age microstructural properties of cement paste. Construction and Building Materials, 52, 189-193.

Bernal, S. A., Nicolas, R. S., Myers, R. J., de Gutierrez, R. M., Puertas, F., van Deventer, J. S. J., and Provis, J. L., 2014. MgO content of slag controls phase evolution and structural changes induced by accelerated carbonation in alkali-activated binders. Cement Concrete Research, 57, 33-43.

Bérubé, M.-A. and Duchesne, J., 1992. Does Silica Fume merely postpone Expansion due to AlkaliAggregate Reactivity?. $9^{\text {th }}$ International Conference on Alkali-Aggregate Reaction in Concrete, 27-31 July, 1992, London, 71-80.

Bleszynski, R., Hooton, R.D., Thomas, M.D.A. and Rogers, C.A., 2002. Durability of ternary blend concrete with silica fume and blast-furnace slag: Laboratory and exposure site studies. ACI Materials Journal, 99, 499-508.

Carlsen, R. and Vennesland, Ø., 1982. Sulfate and sea water durability of concrete. (In Norwegian), SINTEF Report STF65 F82010.

Chappex, T. and Scrivener, K.L., 2012a. Alkali fixation of C-S-H in blended cement pastes and its relation to alkali silica reaction. Cement and Concrete Research. 42, 1049-1054.

Chappex, T. and Scrivener, K.L., 2012b. The influence of aluminum on the dissolution of amorphous silica and its relation to alkali silica reaction. Cement and Concrete Research, 42, 1645-1649.

Chappex, T. and Scrivener, K.L., 2013. The Effect of Aluminum in Solution on the Dissolution of Amorphous Silica and its Relation to Cementitious Systems. J. Am. Ceram. Soc., 96, 592-597.

Danner, T., 2013. Reactivity of Calcined Clays. Thesis (PhD) at NTNU (Norwegian University of Science and Technology), 2013:218, 229 pp.

De Weerdt, K. and Justnes, H., 2008. Microstructure of Binder from the Pozzolanic Reaction between Lime and Siliceous Fly Ash, and the Effect of Limestone Addition. $1^{\text {st }}$ International Conference on Microstructure Related Durability of Cementitious Composites, 13-15 October, 2008, Nanjing, China, RILEM Proceeding PRO 61, 107-116.

De Weerdt, K. and Justnes, H., 2009. Synergic Reactions in Triple Blended Cements. $11^{\text {th }} N C B$ International Seminar on Cement and Building Materials, 17-20 November, New Delhi, India, 257-261.

De Weerdt, K., Justnes, H., Kjellsen, K.O. and Sellevold, E.J., 2010. Fly Ash-Limestone Ternary Composite Cements: Synergy Effect at 28 days. Nordic Concrete Research, Publication No. 42, 2/2010, 51-70 (ISBN: 978-82-8208-023-1).

De Weerdt, K., Kjellsen, K.O., Sellevold, E.J. and Justnes, H., 2011a. Synergy between Fly Ash and Limestone Powder in Ternary Cements. Cement and Concrete Composites, 33, 30-38.

De Weerdt, K., Ben Ha-Ha, M., Le Saout, G., Kjellsen, K.O., Justnes, H. and Lothenbach, B., 2011b. Hydration mechanism of ternary Portland cements containing limestone powder and fly ash. Cement and Concrete Research, 41, 279-291.

De Weerdt, K., Sellevold, E.J., Kjellsen, K.O. and Justnes, H., 2011c. Fly ash - Limestone Ternary Cements - Effect of Component Fineness. Advances in Cement Research, 23, 203-214.

De Weerdt, K., Justnes, H. and Kjellsen, K.O., 2011d. Synergic Effect between Fly Ash and Limestone Powder in Portland Composite Cements”, XXI Nordic Concrete Research Symposium, Hämeenlinna, Finland, May 2011, Nordic Concrete Research Publication No. 43, 297-300.

De Weerdt, K., Østnor, T.A., Justnes, H., Ben Haha, M. and Kjellsen, K.O., 2013. Fly ash - limestone synergy in triple cement. $1^{\text {st }}$ International Conference on Concrete Sustainability, May 27-29, 2013, Tokyo, Japan, Paper S2-2-4, 510-515 (ISBN 978-4-86384-041-6-C3050).

De Weerdt, K., Justnes, H. and Geiker, M.R., 2014. Changes in the phase assemblage of concrete exposed to sea water. Cement and Concrete Composites, 47, 53-63

EN 934-2:2009. European Standard: Admixtures for Concrete, Mortar and Grout. Part 2: Concrete Admixtures - Definitions, Requirements, Conformity and Labelling. CEN (European Committee for 
Standardization), $28 \mathrm{pp}$.

Dehwah, H.A.F., 2007. Effect of sulfate concentration and associated cation type on concrete deterioration and morphology changes in cement hydrates. Construction and Building Materials, 21, 2939.

Duchesne, J., 2012. Deterioration of concrete by the oxidation of sulphide minerals in the aggregate. $1^{\text {st }}$ International Congress on Durability of Concrete ( $\left.1^{\text {st }} I C D C\right)$, Trondheim, Norway, 18-21 June, 2012 (ISBN 978-82-8208-031-6).

Engelsen, C.J. and Justnes, H., 2014. $\mathrm{CO}_{2}$-Binding by Concrete Structures during Life Cycle. $2^{\text {nd }}$ International Congress on Durability of Concrete ( $\left.2^{\text {nd }} I C D C\right)$, 4-6 December 2014, New Delhi, India, Paper 65, 10 pp.

Favier, A.R., Dunant, C.F. and Scrivener, K.L., 2014. Alkali silica reaction mitigation properties of ternary blended cements with calcined clay and limestone. $2^{\text {nd }}$ International Congress on Durability of Concrete ( $2^{\text {nd }}$ ICDC), 4-6 December 2014, New Delhi, India, Paper 11, 7 pp.

Fidjestøl, P. and Frearson, J., 1994. High-performance concrete using blended and triple blended binders. ACI International Conference on High Performance Concrete, Singapore, ACI SP-149.

Fidjestøl, P. and Justnes, H., 2004. Long Term Experience with Microsilica Concrete in a Marine Environment, Nordic Concrete Research, Publication No. 31, 1/2004, 30-39.

Forss, B., 1983. F-cement, a new low-porosity slag cement, Sil. Ind. 48, 79-82.

Fournier, B., Nkinamubanzi, P.C. and Chevrier, R., 2004. Comparative field and laboratory investigations on the use of supplementary cementing materials to control alkali-silica reactions in concrete. $12^{\text {th }}$ International Conference on Alkali-Aggregate Reaction in Concrete (ed. T. Mingshu and D. Min), 1, 528-537.

Ghafoori, N., Najimi, M., Diawara, H. and Islam, M.S., 2015. Effects of class F fly ash on sulphate resistance of Type V Portland cement concretes under continuous and interrupted sulfate exposures. Construction and Building Materials, 78, 85-91.

Giergiczny, Z., Glinicki, M.A., Sokołowski, M. and Zielinski, M., 2009. Air void system and frost-salt scaling of concrete containing slag-blended cement. Construction and Building Materials, 23, 24512456.

Hinrichs, W. and Odler, I., 1989. Investigation of the hydration of Portland blast furnace slag cement: hydration kinetics. Advances in Cement Research, 2, 15-20.

Hoang, K D , 2012. Hardening Accelerator for Fly Ash Blended Cement. Thesis (PhD) at NTNU (Norwegian University of Science and Technology) 2012:336, 195 pp.

Hoang K.D., Geiker, M.R., Justnes, H., Rudberg, E. and Myrdal, R., 2013. Hardening-Accelerator and a Method for Accelerating the Hardening of Hydraulic Binders and Mixtures Thereof. WO2013066192 (A1) - 2013-05-10.

Hobbs, D.W., 1986. Carbonation of concrete containing pfa. Magazine of Concrete Research, 40, 143.

Hossack, A.M. and Thomas, M.D.A., 2015. Varying fly ash and slag contents in Portland limestone cement mortars exposed to external sulfates. Construction and Building Materials, 78, 333-341.

Irassar, E.F., 2009. Sulfate attack on cementitious materials containing limestone filler - A review. Cement and Concrete Research, 39, 241-254.

Jolicoeur C., To T.C., Benoît, É., Hill, R., Zhang, Z. and Pagé, M., 2009. Fly Ash Carbon Effects on AirEntrainment: "Fundamental Studies on their Origin and Chemical Mitigation. World of Coal Ash (WOCA), May 4-7, 2009, Lexington, KY, USA, 23 pp.

Justnes, H., 1992. Hydraulic binders based on condensed silica fume and slaked lime, $9^{\text {th }}$ International Congress on the Chemistry of Cement, New Delhi, India, 23-28 November, III, 284-290.

Justnes, H., 1995. Accelerated Hardening of Mortars with Hydraulic Binders of Silica Fume/Lime. Nordic Concrete Research, Publication No. 17, 2/1995, 30-41.

Justnes, H., 1998. Kinetics of Reaction in Cementitious Pastes Containing Silica Fume as Studied by ${ }^{29} \mathrm{Si}$ MAS NMR. in Nuclear Magnetic Resonance Spectroscopy of Cement-based Materials (Eds. P. Colombet, A.-R. Grimmer, H. Zanni and P. Sozzani), Springer Verlag, Berlin, 245-268.

Justnes, H., 2007. Silica Fume in High-Quality Concrete - A Review of Mechanism and Performance. $9^{\text {th }}$ 
CANMET/ACI International Conference on Fly Ash, Silica Fume, Slag and Natural Pozzolans in Concrete, ACI SP-242, Ed. Mohan Malhotra, Warszawa, Poland, 21-25 ${ }^{\text {th }}$ May, 2007, SP-242-6, 63-78.

Justnes, H., 2013. How to make concrete more sustainable, $1^{\text {st }}$ International Conference on Concrete Sustainability, May 27-29, Tokyo, Japan, Paper S1-1-2, 92-99 (ISBN 978-4-86384-041-6-C3050).

Justnes, H. and Geiker, M.R., 2012. A Critical View on Service Life Predictions based on Chloride Induced Corrosion. $2^{\text {nd }}$ International Conference on "Microdurability" (Microstructure Related Durability of Cementitious Composites). Amsterdam, the Netherlands, 11-13 April, 2012, 13 pp.

Justnes, H. and Ng. S., 2014. Concrete Admixtures - Interactions with Cement, Supplementary Cementing Materials and Fillers. $3^{\text {rd }}$ International Symposium on Design, Performance and Use of SelfConsolidating Concrete, SCC'2014-China, June 5-8, 2014, Xiamen, China, RILEM Proceedings PRO 93, p. 138 (ISBN 978-2-35158-143-8, e-ISBN 978-2-35158-144-5).

Justnes, H. and Østnor, T.A., 2014a. Durability and microstructure of mortar with calcined marl as supplementary cementing material, XIII conference on Durability of Building Materials and Components (DBMC), Sao Paulo, Brazil, September 3-5, 2014, 771-780

Justnes, H. and Østnor, T.A., 2014b. Designing Alternative Binders Utilizing Synergic Reactions, $5^{\text {th }}$ International Conference on Non-traditional Cement and Concrete (NTCC2014), Edited by V. Bílek and Z. Keršner, 16-19 June, 2014, Brno, Czech Republic, 101-104 (ISBN 978-80-214-4867-4).

Justnes, H., Meland, I., Bjørgum, J.O. and Krane, J., 1990. A ${ }^{29}$ Si MAS NMR Study of the Pozzolanic Activity of Condensed Silica Fume and the Hydration of Di- and Tricalcium Silicate. Advances in Cement Research, 3, 111-116.

Justnes, H., Sellevold, E.J. and Lundevall, G. (1992). High Strength Concrete Binders. Part A: Reactivity and Composition of Cement Pastes with and without Condensed Silica Fume. $4^{\text {th }}$ ACI International Conference on Fly Ash, Silica Fume, Slag and Natural Pozzolana in Concrete, Ed.: V.M. Malhotra, Istanbul, May 3-8, 1992, CANMET/ACI SP 132-47, 2, 873-889.

Kjellsen, K.O, Detwiler, R.J. and Gjørv, O.D., 1990a. Back scattered electron imaging of cement pastes hydrated at different temperatures. Cement and Concrete Research, 20, 308-311.

Kjellsen, K.O, Detwiler, R.J. and Gjørv, O.D., 1990b. Pore structure of plain cement pastes hydrated at different temperatures. Cement and Concrete Research, 20, 927-933.

Kjellsen, K.O, Detwiler, R.J. and Gjørv, O.D., 1991. Development of microstructure in plain cement pastes hydrated at different temperatures. Cement and Concrete Research, 21, 179-189.

Kunther, W., Lothenbach, B. and Scrivener, K.L., 2013. Influence of bicarbonate ions on the deterioration of mortar bars in sulfate solutions. Cement and Concrete Research, 44, 77-86.

Lee, C.Y., Lee, H.K. and Lee, K.M., 2003. Strength and microstructural characteristics of chemically activated fly ash-cement systems. Cement and Concrete Research, 33, 425-431.

Lothenbach, B., Le Saout, G., Gallucci, E. and Scrivener, K., 2008. Influence of limestone on the hydration of Portland cements. Cement and Concrete Research, 38, 848-860.

Lothenbach, B., Scrivener, K. and Hooton, R.D., 2011. Supplementary cementing materials. Cement and Concrete Research, 41, 1244-1256.

Müllauer, W., Beddoe, R.E., Hilbig, H. and Heinz, D., 2012. Mechanisms of sulfate attack for plain and fly ash cements at different storage temperatures and sulfate concentrations, $1^{\text {st }}$ International Congress on Durability of Concrete ( $1^{\text {st }} I C D C$ ), Trondheim, Norway, 18-21 June, PP3, 12 pp.

Ng, S. and Justnes, H., 2014a. Rheological Properties and Early Hydration of Blended Cement Pastes with PCE Plasticizers, $3^{\text {rd }}$ International Symposium on Design, Performance and Use of SelfConsolidating Concrete, SCC'2014-China, June 5-8, 2014, Xiamen, China, RILEM Proceedings PRO 93, 162-169 (ISBN 978-2-35158-143-8, e-ISBN 978-2-35158-144-5).

Ng, S. and Justnes, H., 2014b. A Comparison on the Roles of Plasticizers in the Rheology and Hydration of Blended Cements, $6^{\text {th }}$ International Conference of the Asian Concrete Federation (ACF), 21-24 September, 2014, Seoul, South Korea, 614-618.

Palacios, M, Houst, YF, Bowen, P and Puertas, F, 2009. Adsorption of superplasticizer admixtures on alkali-activated slag pastes. Cement and Concrete Research, 39, 670-677.

Panesar, D.K. and Chidiac, S.E., 2007. Multi-variable statistical analysis for scaling resistance of concrete 
containing GGBFS, Cement \& Concrete Composites, 29, 39-48.

Qian, J., Shi, C. and Wang, Z., 2001. Activation of blended cements containing fly ash. Cement and Concrete Research, 31, 1121-1127.

Ramlochan, T., Zacarias, P., Thomas, M.D.A. and Hooton, R.D., 2003. The effect of pozzolans and slag on expansion of mortars cured at elevated temperature. Part I. Expansive behavior. Cement and Concrete Research, 33, 807-814.

Ramlochan, T., Thomas, M.D.A. and Hooton, R.D., 2004. The effect of pozzolans and slag on expansion of mortars cured at elevated temperature. Part II. Microstructural and microchemical investigations. Cement and Concrete Research, 34, 1341-1356.

Regourd, M., 1980. Structure and behaviour of slag Portland cement hydrates. $7^{\text {th }}$ International Congress on the Chemistry of Cement, Paris, 1980, Vol. I, pp. III-2/10-III-2/26.

Richartz, W., 1966. On the formation of the aluminous hydrate phases during setting of cement, Tonind.Ztg., 90, 449-457.

Rønne, M., Hammer, T.A., Justnes, H., Meland, I.S. and Jensen, V., 1995. Chemical Stability of LWAC Exposed to High Hydration Generated Temperatures. International Symposium on Structural Lightweight Aggregate Concrete, Sandefjord, Norway, 20-24 June, 505-516.

Scrivener, K.L., 2012. Understanding and establishing sulfate resistance of cementitious materials, $1^{\text {st }}$ International Congress on Durability of Concrete ( $1^{\text {st }}$ ICDC), Trondheim, Norway, 18-21 June, 2012 (ISBN 978-82-8208-031-6). KN2, 8pp.

Scrivener, K.L., Lothenbach, B., De Belie, N., Gruyaert, E., Skibsted, J., Snellings, R. and Vollpracht, A., 2015. RILEM TC 238-SCM: hydration and microstructure of concrete with SCMs. Materials and Structures, DOI 10.1617/s11527-015-0527-4.

Sellevold, E.J. and Justnes, H., 1992. High-Strength Concrete Binders. Part B: Non-evaporable Water, Self-desiccation and Porosity of Cement Pastes with and without Condensed Silica Fume. $4^{\text {th }}$ CANMET/ACI International Conference on Fly Ash, Silica Fume, Slag and Natural Pozzolana in Concrete, Ed.: V.M. Malhotra, Istanbul, May 3-8, 1992, CANMET/ACI SP 132-48, 2, 891-902.

Shehata, M.H. and Thomas, M.D.A., 2000. The effect of fly ash composition on the expansion of concrete due to alkali silica reaction. Cement and Concrete Research, 30, 1063-1072.

Shehata, M.H. and Thomas, M.D.A., 2002. Use of ternary blends containing silica fume and fly ash to suppress expansion due to ASR in concrete. Cement and Concrete Research, 32, 341-349.

Shi, C., and Day, L.R., 1995. Acceleration of the reactivity of fly ash by chemical activation. Cement and Concrete Research, 25, 15-21.

Shi, C. and Day, L.R., 2000a. Pozzolanic reaction in the presence of chemical activators, Part I. Reaction kinetics. Cement and Concrete Research, 30, 51-58.

Shi, C. and Day, L.R., 2000b. Pozzolanic reaction in the presence of chemical activators, Part II. Reaction products and mechanisms. Cement and Concrete Research, 30, 607-613

Shi, C. and Day, L.R., 2001. Comparison of different methods for enhancing reactivity of pozzolans. Cement and Concrete Research, 31, 813-818.

Sisomphon, K., Copuroglu, O. and Fraaij, A.L.A., 2010. Development of blast furnace slag mixtures against frost salt attack. Cement \& Concrete Composites, 32, 630-638.

Smolczyk, H.-G., 1965. The hydration products of cements with high contents of blast furnace slag, Zement-Kalk-Gips International, 18, 238-246.

Thomas, M.D.A., 2011. The effect of supplementary cementing materials on alkali silica reaction: A review. Cement and Concrete Research, 41, 1224-1231.

Thomas, M., 2013. Supplementary Cementing Materials in Concrete. $1^{\text {st }}$ Ed. CRC Press, Taylor \& Francis Group, 190 pp. (ISBN 978-1-4665-7298-0).

Thomas, M.D.A. and Bamforth, P.B., 1999. Modelling chloride diffusion in concrete - Effect of fly ash and slag. Cement and Concrete Research, 29, 487-495.

Thomas, M.D.A. and Innes, F.A., 1998. Effect of slag on expansion due to alkali aggregate reaction in concrete. ACI Materials Journal, 95 (6)

Thomas, M.D.A., Shehata, M.H., Shashiprakash, S.G., Hopkins, D.S. and Cail, K., 1999. Use of ternary 
cementitious systems containing silica fume and fly ash in concrete. Cement and Concrete Research, 29, 1207-1214.

Thomas, M.D.A., Matthews, J.D. and Haynes, C.A., 2000. Carbonation of fly ash concrete. $4^{\text {th }}$ CANMET/ACI International Conference on Durability of Concrete, ACI SP-192, 1, 539-556.

Uchikawa, H., 1986. Effect of blending components on hydration and structure formation. $8^{\text {th }}$ International Congress on the Chemistry of Cement, Rio de Janeiro, 1, 249-280.

Utgennant, P, 2004. The influence of ageing on the salt-frost resistance of concrete. Thesis (PhD), Report TVBM-1021, Division of Building Materials, Lund Institute of Technology, Lund University, Sweden, 346 pp (ISBN 91-628-6000-3).

Vikan, H. and Justnes, H., 2007. Rheology of cementitious paste with silica fume and limestone. Cement and Concrete Research, 37, 1512-1517

Visser , J.H.M., 2014. Influence of the carbon dioxide concentration on the resistance to carbonation of concrete. Construction and Building Materials, 67, 8-13.

Zajac, M., Bremseth, S.K., Whitehead, M. and Ben Haha, M., 2014. Effect of $\mathrm{CaMg}\left(\mathrm{CO}_{3}\right)_{2}$ on hydrate assemblages and mechanical properties of hydrated cement pastes at $40^{\circ} \mathrm{C}$ and $60^{\circ} \mathrm{C}$, Cement and Concrete Research, 65, 21 -29. 